\title{
Could fibrinogen and hsCRP be useful for assessing personal risk in workers exposed to a mixture of ultrafine particles and organic solvents?
}

\author{
Septimiu Voidazan ${ }^{1}$, Horaţiu Moldovan ${ }^{2 *}$, Adina Huţanu ${ }^{3}$, Doina Giurgiu ${ }^{4}$, Stelian \\ Morariu $^{5}$, Lode Godderis ${ }^{6,7}$, Radu-Corneliu Duca ${ }^{6}$
}

1. Department of Epidemiology, University of Medicine and Pharmacy of Tîrgu Mureş, Romania

2. Department of Occupational Medicine, University of Medicine and

Pharmacy of Tîrgu Mureş, Romania

3. Department of Laboratory Medicine, CCAMF, University of

Medicine and Pharmacy of Tîrgu Mureș, Romania

4. Department of Occupational Medicine, University "Lucian Blaga" Sibiu, Romania

5. Department of Occupational Medicine, West University "Vasile Goldis" Arad, Romania

6. Centre for Environment and Health, Department of Public Health and

Primary Care, University of Leuven (KU Leuven), Belgium

7. IDEWE, External service for prevention and protection at work, Heverlee, Belgium

\begin{abstract}
Purpose: Our study focuses on elucidating if two common inflammatory biomarkers, easily performed in any laboratory - high-sensitivity C-reactive protein (hsCRP), as well as fibrinogen - could be used to assess the personal health risk of workers exposed to a complex occupational exposure to ultrafine particles (UFP) and a mixture of organic solvents. Methods: To assess the inflammatory response on the body, laboratory determinations were performed by testing the serum levels of hsCRP and fibrinogen, in exposed and unexposed groups. Results: There are no statistically significant differences for hsCRPs (p-0.25), medians were similar in groups. The mean values of fibrinogen in the three groups were: in the workers group (1st group): $346.2 \mathrm{mg} / \mathrm{dl}$, in the office staff group (2nd group): $328.7 \mathrm{mg} / \mathrm{dl}$, and in the control group (3rd group): $284.8 \mathrm{mg} / \mathrm{dl}$, with significant differences between 1 st group vs 3rd group and between 2nd group vs 3rd group (p-0.002). UFP levels differ between the groups, as follows: 1st group were exposed to the highest levels, ranging from 48349 to 3404000 part/cm3; 2nd group, ranging from 17371 to 40595 part/cm3; and 3rd group, ranging from 213 to 16255 part/cm3. Conclusions: Our study demonstrates that fibrinogen is a useful inflammatory biomarker for exposure to a mixture of UFP and organic solvents. On the other hand, hsCRP is not a useful inflammatory biomarker in occupational exposure to UFP and organic solvents. Further studies are needed to demonstrate the extent to which fibrinogen is more or less influenced by organic solvents or UFP alone.
\end{abstract}

Keywords: ultrafine particles, solvents, occupational exposure, fibrinogen, high-sensitivity C-reactive protein

Received: $21^{\text {st }}$ November 2017; Accepted: $4^{\text {th }}$ March 2018; Published: $28^{\text {th }}$ March 2018

*Corresponding author: Horatiu Moldovan, University of Medicine and Pharmacy of Tîrgu Mureş Tîrgu Mureş, Romania. E-mail: moldovan.horatiu@umftgm.ro 


\section{Background}

Nowadays, workers are exposed to a range of ultrafine particles (UFP) comprising manufactured nanoparticles and particles coming from natural, human or industrial sources. Workers are exposed to UFP, either in nanoparticle production processes or during the transport of these materials, but especially when using nanoparticles and nanomaterials. Workers are susceptible to their toxic action, most likely by inhalation [1]. Furthermore, it is well known that in most of the 'nano-exposed' workplaces there is not only a single but a complex exposure to other chemicals, especially to organic solvents.

The effects of organic solvents on human body are well known for decades. Different types of cancers (blood, renal, breast, lung, liver) have been associated with organic solvents exposure, as well as a wide range of non-cancerous health effects such as functional aberration of vital systems in the body like reproductive, immune, nervous, endocrine, cardiovascular, digestive and respiratory [2-5]. Industrial solvents are also known as a source of free radicals in the body, which could furthermore explain their multiple role in a wide range of pathologies [6].

Unlike for solvents, the effects of nanoparticles on health are not yet fully understood, and even less is known about the effects of simultaneous exposure to ultrafine particles and solvents. Previous studies reported that nanoparticle exposure might result in lung diseases (pulmonary fibrosis, granulomatosis, inflammation of the pulmonary parenchyma, bronchial asthma, lung cancer), cardiovascular ones, such as atherosclerosis [7-9].

Thus, evaluation of the toxic effects that heterogeneous complex mixtures might induce is a current challenge, since the number and type (e.g. nanoparticles) of materials are constantly evolving. Several biomarkers are currently studied, such as markers of inflammation (e.g. C-re- active protein-hsCRP, fibrinogen) [10]. Plasma hsCRP is usually low in normal individuals but can be up-regulated rapidly in response to injury, infection, and other inflammatory stimuli, even in particulate matter exposure. Most animal studies provide strong evidence that hsCRP levels increase after particulate matter exposure $[11,12]$. Other studies have investigated the role of hsCRP in particle-mediated systemic inflammation and found that exposure to ambient particles increase blood C-reactive protein levels in humans $[13,14]$ and rats [15].

Knowing that fibrinogen is up-regulated in inflammation and is associated with the cardiovascular effects observed after environmental particle exposures, Peters A. et al., [16] hypothesized that fibrinogen acts to coat and aggregate discrete matter, to increase particle size upwards of the nano-range and to accelerate this process at increased concentrations.

In this context, our study aimed at the assessment of the toxic effects of a complex mixture of ultrafine particles and organic solvents, as reflected by the serum levels of C-reactive protein and fibrinogen, together with the clinical evaluation of exposed workers and members of the unexposed group.

\section{Materials and Methods}

\section{Study design}

The research was based on a cross-sectional study that included three groups. In the $1^{\text {st }}$ group 20 workers from the areas concerning the production of paints and thermoplastic panels based on $\mathrm{TiO}_{2}$, varnishes, plasters, and composite materials were included. These workers are usually performing a day by day activity ( 8 hours a day in two shifts) consisting in casting of fiberglass-reinforced polyester composite sheets, hot sanding of sheets, mixing various substances in the process of making washable paints. All operations are carried out in a large hall divided into 
3 open spaces with a wide communication in between. Most of the workers in the production area perform rather static work, in a limited area. In the $2^{\text {nd }}$ group 30 workers from the staff area of the factory, just nearby the main production hall were included; their location is separated from the production area by simple doors, without an air/water curtain. All the office workers have occasional responsibilities in the production area, but they usually spend a short time in that area for checking systems and quality control. In the $3^{\text {rd }}$ group (control group) 70 out-of-factory people who only perform office work as civil servants in a public institution were included.

The study was approved by the Ethics Committee of the University of Medicine and Pharmacy of Tîrgu Mureş, Romania, and a collaboration protocol was established with the factory where the workers are performing. Due to the confidentiality provisions, we cannot disclose the name of the factory, as well as its location, except the country, Romania.

Subjects included in the research received information about the objectives of the study and signed an informed consent issued in compliance with the Helsinki Declaration. Demographics (age, gender, seniority at work), laboratory results, biological samples were used only for the purpose of the project protocol. No names were used, and the subjects' privacy and anonymity were preserved.

We excluded subjects who had had intense physical activity before sampling or had been administered certain medicines, such as non-steroidal anti-inflammatory drugs (aspirin or ibuprofen), corticosteroids, hypolipemiants (statins), hormonal treatment of any type. Subjects on oral contraceptives, pregnant, obese or with cardiovascular disorders were also excluded.

\section{Exposure evaluation}

Ultrafine particles exposure. Measurements of ultrafine particles level in the work place were done using an Aerasense NanoTracer (Phillips, Eindhoven, The Netherlands) [17]. The nanoTraces is a portable device allowing the repeated (time resolution 16s) determination of number concentration and average particle size of particles between 20 and $120 \mathrm{~nm}$. Stationary measurements for $1 \mathrm{~h}$ have been done in different work places following the working cycles.

Solvents exposure. Exposure to volatile organic compounds (VOCs) has been evaluated using passive organic vapor monitors $\left(3 \mathrm{M}^{\mathrm{TM}} 3500\right.$ monitors, 3M Company, Saint Paul, US) that were analyzed using a gas chromatography coupled with a flame ionization detector (GC-FID) method allowing the identification and quantification of 185 VOCs. Detailed description about the method and analytical performances has been published elsewhere [18].

\section{Clinical evaluation}

Subjects were examined according to the following schedule: physical examination, occupational history based on a specific questionnaire, smoking and alcohol consumption habits. Biological sampling for the workers was performed during the work shift, towards the end of the working day and during the second part of the week.

\section{Biochemical measurements}

Blood tests were performed to determine the level of C-reactive protein and fibrinogen as markers of inflammation and tissue damage. hsCRP levels have been measured using a clinical chemistry analyser Cobas Integra 400 plus. The following hsCRP cut-off points were recommended for cardiovascular disease risk assessment: $<1.0 \mathrm{mg} / 1$ for a low relative risk, $1.0-3.0$ $\mathrm{mg} / \mathrm{l}$ for an average relative risk, and $>3.0 \mathrm{mg} / \mathrm{l}$ for and increased relative risk.

For fibrinogen measurements a STA ${ }^{\circledR}$-Liquid Fib Kit was used on a STA-R ${ }^{\circledR}$, STA Compact $^{\circledR}$ and STA Satellite ${ }^{\circledR}$ for the quantitative determi- 
nation of fibrinogen levels in plasma by the clotting method of Clauss [19]. Sample collection was in conformity with the recommendations for haemostasis tests. Blood (9 vol.) was collected in $0.109 \mathrm{M}$ (i.e., $3.2 \%$ ) trisodium citrate anticoagulant (1 vol.). Centrifugation: 15 minutes at 2000-2500 g. Plasma storage: 8 hours at $20 \pm 5$ ${ }^{\circ} \mathrm{C}$. The normal plasma fibrinogen level in the adult population was in the range of 2-4 g/l (200$400 \mathrm{mg} / \mathrm{dl})$.

\section{Data recording and analysis}

The data were collected in Excel. Statistical analysis was performed using the Statistical Package for Social Sciences (SPSS, version 22, Chicago, IL, USA). To assess the normality of continuous variables (i.e. hsCRP, Fibrinogen), the Shapiro-Wilk test was used. ANOVA test was used to assess the differences between means of continuous variables (expressed as mean $\pm \mathrm{SD}$ ), while differences between nonparametric variables (expressed as median, range) were compared using the Kruskal Wallis tests. By using Bonferroni and Dunn's multiple comparison tests, we found the groups between which there were statistically significant differences. We interpreted all tests against a $\mathrm{p}=0.05$ significance threshold and statistical significance was considered for $\mathrm{p}$-values below the significance threshold.

\section{Results}

\section{Studied population}

A total of 120 subjects aged 27-57 years old (mean $=42.3$ years) were included in the study of which $54.4 \%$ were male. The different groups consisted of: 20 factory workers with mean age of 41.9 years ( $1^{\text {st }}$ group); 30 office staff subjects, employed in the same factory, with mean age of 42.6 years ( $2^{\text {nd }}$ group); and 70 public servants, from a public government institution, with mean age of 42.5 years ( $3^{\text {rd }}$ group). Groups were matched for age, sex, body mass index, but differ upon health status. Current working place seniority was not statistically different (p-0.47) between the $1^{\text {st }}$ group (median 4.77 years) and $2^{\text {nd }}$ group (median 4 years). Also, total occupational seniority was not statistically different (p0.29 ) between the two factory groups (median 19.5 years and 18 years, respectively).

The workers' past medical history reveals that smoking habit is present in $60 \%$ of the workers in the $1^{\text {st }}$ group, $46.6 \%$ in the $2^{\text {nd }}$ group and $35.7 \%$ in the $3^{\text {rd }}$ group. Similar data reflect occasional alcohol consumption: $70 \%$ in the $1^{\text {st }}$ group, $60 \%$ in the $2^{\text {nd }}$ group and $40.0 \%$ in the $3^{\text {rd }}$ group. Considering smoking habit and occasional alcohol consumption, we have not identified a statistically significant difference between the exposed groups ( $1^{\text {st }}$ and $\left.2^{\text {nd }}\right)$ and control ( $3^{\text {rd }}$ group), (p-0.49 for smoking, and p-0.70 for alcohol).

\section{Exposure evaluation}

Ultrafine particle levels (table 1) differ between the groups, as follows: $1^{\text {st }}$ group - factory workers were exposed to the highest levels of exposure, ranging from 48349 to 3404000 part/ $\mathrm{cm}^{3} ; 2^{\text {nd }}$ group - factory office staff were exposed to lower levels of UFP than the factory workers, ranging from 17371 to $40595 \mathrm{part} / \mathrm{cm}^{3}$; and the $3^{\text {rd }}$ group - control group were exposed to environmental levels of UFP, ranging from 213 to $16255 \mathrm{part} / \mathrm{cm}^{3}$. Apart from the actual levels of exposure the type of ultrafine particle differed between the groups with very small particles (20 to $64 \mathrm{~nm}$ diameter) for $1^{\text {st }}$ group, and similar particle size for both $2^{\text {nd }}$ group and $3^{\text {rd }}$ group (63 to $110 \mathrm{~nm}$ and 64 to $108 \mathrm{~nm}$ diameter, respective$1 y)$.

Among the 185 VOCs compounds screened for, only three solvents have been identified in the factory: styrene, acetone and toluene. OSHA-recommends different occupational exposure limits for these solvents: styrene $-85 \mathrm{mg} /$ 
$\mathrm{m}^{3}$, acetone - $1187 \mathrm{mg} / \mathrm{m}^{3}$ and toluene $-75 \mathrm{mg}$ / $\mathrm{m}^{3}$, Threshold Limit Values (TLV) issued by the American Conference of Governmental Industrial Hygienists (ACGIH). As for UFP, the $1^{\text {st }}$ group had the highest exposure to the organic solvents: styrene ranging from 3 to $218 \% \mathrm{TLV}$, acetone ranging from 0.4 to $28 \%$ TLV, and toluene with levels lower than $2 \%$ TLV. The $2^{\text {nd }}$ group has shown a moderate exposure to solvents: styrene lower than 7\% TLV, acetone lower than $1 \%$ TLV and toluene lower then $0.5 \%$ TLV. For the $3^{\text {rd }}$ group, the levels of solvents were below the limits of quantification of the analytical method (i.e styrene, $0.12 \mu \mathrm{g} / \mathrm{m}^{3}$; acetone, 0.22 $\mu \mathrm{g} / \mathrm{m}^{3}$; toluene, $\left.0.1 \mu \mathrm{g} / \mathrm{m}^{3}\right)$. (Table 1)

\section{Clinical evaluation}

BMI varies among the workers' groups, from $25.43 \pm 4.4 \mathrm{~kg} / \mathrm{m}^{2}$ for the $1^{\text {st }}$ group, to $25.02 \pm 3.9$ $\mathrm{kg} / \mathrm{m}^{2}$ for the $2^{\text {nd }}$ group and $26.30 \pm 4.3 \mathrm{~kg} / \mathrm{m}^{2}$ for the $3^{\text {rd }}$ group $(\mathrm{p}>0.05)$.

Blood pressure, as well as heart rate are normal across the three groups.

Despite the polymorphism of the symptoms and diseases revealed during the clinical examination, we have found a higher incidence of respiratory conditions among the workers in the $1^{\text {st }}$ group $(35.0 \%)$ and the $2^{\text {nd }}(14.8 \%)$, while musculoskeletal disorders are dominant among the workers in the $3^{\text {rd }}$ group $(25.3 \%)$.

\section{Biochemical measurements}

Since the data for hsCRP did not follow a Gaussian distribution, we used a Kruskal-Wallis test for the statistical analysis. This test revealed that there are no statistically significant differences between hsCRP $(p=0.25)$, even if median values are showing an increasing tendency

Table 1. Exposure level to ultrafine particles and organic solvents

\begin{tabular}{|c|c|c|c|c|c|c|c|}
\hline & & & Minimum & Median & Maximum & Mean & Std. Dev. \\
\hline \multicolumn{8}{|c|}{ Workers (1 $1^{\text {st }}$ group) } \\
\hline \multirow[t]{2}{*}{ UFP } & No. & part. $/ \mathrm{cm}^{3}$ & 48349 & 574854 & 3404000 & 715845 & 587574 \\
\hline & $\mathrm{dp}$ & $\mathrm{nm}$ & 20 & 28 & 64 & 32 & 11 \\
\hline \multirow[t]{3}{*}{ Solvents } & Styrene & $\mu \mathrm{g} / \mathrm{m}^{3}$ & 2783 & 45317 & 185563 & 48517 & 36318 \\
\hline & Acetone & $\mu \mathrm{g} / \mathrm{m}^{3}$ & 4377 & 9264 & 335983 & 60206 & 103702 \\
\hline & Toluene & $\mu \mathrm{g} / \mathrm{m}^{3}$ & 34 & 680 & 1436 & 668,4 & 462 \\
\hline \multicolumn{8}{|c|}{ Office staff ( $2^{\text {nd }}$ group) } \\
\hline \multirow[t]{2}{*}{ UFP } & No. & part $/ \mathrm{cm}^{3}$ & 17371 & 21560 & 40595 & 22226 & 3131 \\
\hline & $\mathrm{dp}$ & $\mathrm{nm}$ & 63 & 95 & 110 & 94 & 7 \\
\hline \multirow[t]{3}{*}{ Solvents } & Styrene & $\mu \mathrm{g} / \mathrm{m}^{3}$ & 272 & 1243 & 5911 & 2166 & 1995 \\
\hline & Acetone & $\mu \mathrm{g} / \mathrm{m}^{3}$ & 333 & 1294 & 7854 & 2489 & 2435 \\
\hline & Toluene & $\mu \mathrm{g} / \mathrm{m}^{3}$ & 70 & 253 & 342 & 232 & 78 \\
\hline \multicolumn{8}{|c|}{ Control (3 $3^{\text {rd }}$ group) } \\
\hline \multirow[t]{2}{*}{ UFP } & No. & part $/ \mathrm{cm}^{3}$ & 213 & 10568 & 16255 & 10058 & 2901 \\
\hline & $\mathrm{dp}$ & $\mathrm{nm}$ & 64 & 89 & 108 & 89 & 9 \\
\hline \multirow[t]{3}{*}{ Solvents } & Styrene & $\mu \mathrm{g} / \mathrm{m} 3$ & $<0.12$ & $<0.12$ & $<0.12$ & $<0.12$ & 0.12 \\
\hline & Acetone & $\mu \mathrm{g} / \mathrm{m} 3$ & $<0.22$ & $<0.22$ & $<0.22$ & $<0.22$ & $<0.22$ \\
\hline & Toluene & $\mu \mathrm{g} / \mathrm{m} 3$ & $<0.10$ & $<0.10$ & $<0.10$ & $<0.10$ & $<0.10$ \\
\hline
\end{tabular}

UFP - ultrafine particles; dp - diameter of the particle (part.) 
(workers $>$ office staff $>$ control), which might be attributed to the different exposure levels: higher exposure for workers, median exposure for office staff and no exposure for the control group. The complete descriptive and inferential statistics for hsCRP are given in Table 2.

Concerning the results for fibrinogen, the obtained data follow a Gaussian distribution allowing us to use an Anova test for the statistical analysis (Table 3 ). The mean values of fibrinogen in the three groups were as follows: in the higher exposure group of $346.2 \mathrm{mg} / \mathrm{dl}$, in the moderate exposed group of $328.7 \mathrm{mg} / \mathrm{dl}$, and in the control group of $284.8 \mathrm{mg} / \mathrm{dl}$, with significant differences between the exposed subjects and the control group (p-0.002).

We further analysed the correlation of hsCRP and fibrinogen levels with different clinical indi-

Table 2. Comparative value of hsCRP in the monitored groups

\begin{tabular}{|c|c|c|c|}
\hline Kruskal-Wallis test & & roups & \\
\hline $\begin{array}{l}\text { hsCRP } \\
(\mathrm{mg} / \mathrm{l})\end{array}$ & $\begin{array}{c}\text { Workers } \\
\left(1^{\text {st }} \text { group }\right) \\
\mathrm{No}=20\end{array}$ & $\begin{array}{c}\text { Office staff } \\
\left(2^{\text {nd }} \text { group }\right) \\
\text { No }=30\end{array}$ & $\begin{array}{c}\text { Control } \\
\left(3^{\text {rd }} \text { group }\right) \\
\mathrm{No}^{2}=70\end{array}$ \\
\hline Minimum & 0.14 & 0.09 & 0.05 \\
\hline Median & 1.92 & 1.42 & 1.04 \\
\hline Maximum & 8.72 & 7.08 & 9.31 \\
\hline Mean & 2.68 & 1.74 & 1.97 \\
\hline Std. Deviation & 2.40 & 1.79 & 2.10 \\
\hline P value & \multicolumn{3}{|c|}{0.25} \\
\hline Do the medians vary signif. $(\mathrm{P}<0.05)$ & No & & \\
\hline Dunn's Multiple Comparison Test & Difference in rank sum & & \\
\hline Workers vs. Office staff & 15.68 & \multirow{3}{*}{$\begin{array}{c}\text { Significant? } \\
\mathrm{P}<0.05 ?\end{array}$} & No \\
\hline Workers vs. Control & 11.36 & & No \\
\hline Office staff vs. Control & -4.318 & & No \\
\hline
\end{tabular}

Table 3. Comparative value of fibrinogen in the monitored groups

\begin{tabular}{|c|c|c|c|}
\hline Anova test & & Groups & \\
\hline $\begin{array}{l}\text { Fibrinogen } \\
(\mathrm{mg} / \mathrm{dl})\end{array}$ & $\begin{array}{c}\text { Workers } \\
\left(1^{\text {st }} \text { group }\right) \\
\mathrm{No}=20\end{array}$ & $\begin{array}{c}\text { Office staff } \\
\left(2^{\text {nd }} \text { group }\right) \\
\mathrm{No}=30\end{array}$ & $\begin{array}{c}\text { Control } \\
\left(3^{\text {rd }} \text { group }\right) \\
\mathrm{No}=70\end{array}$ \\
\hline Minimum & 220.0 & 220.0 & 101.0 \\
\hline Median & 340.0 & 315.5 & 288.0 \\
\hline Maximum & 533.0 & 514.0 & 449.0 \\
\hline Mean & 346.2 & 328.7 & 284.8 \\
\hline Std. Deviation & 75.37 & 78.17 & 73.30 \\
\hline P value & & 0.002 & \\
\hline Are means signif. different? $(\mathrm{P}<0.05)$ & Yes & & \\
\hline Bonferroni's Multiple Comparison Test & Mean Diff. & $\begin{array}{c}\text { Significant? } \\
\mathrm{P}<0.05 ?\end{array}$ & $95 \%$ CI of diff \\
\hline Workers vs. Office staff & 17.52 & ns & -35.85 to 70.89 \\
\hline Workers vs. Control & 61.45 & $* *$ & 14.47 to 108.4 \\
\hline Office staff vs. Control & 43.92 & $*$ & 2.312 to 85.54 \\
\hline
\end{tabular}

${ }^{*} \mathrm{p}<0.01,{ }^{* *} \mathrm{p}<0.001$ 
cators (i.e. systolic blood pressure - SBP, diastolic blood pressure - DBP, heart rate - HR), age and seniority in the current job, distinct for each of the three groups. No significant correlations except for HR in moderate exposed group (office workers) were observed (Table 4).

\section{Discussions}

Previous human and animal studies have described the potential effects of UFP and nanomaterials on human health, like: inflammation, pulmonary fibrosis or cardiovascular effects [7, 20-24]. In this context, the determination of potential toxic effect on human of UFP and/or nanomaterials exposure became important for the timely diagnosis of potential diseases development [8, 25-26]. Thus, in the current study, we investigated whether two widely used and readily available inflammatory markers, namely hsCRP and fibrinogen, could be used for the timely diagnostic of potential systemic effects.

hsCRP is a systemic marker sensitive to inflammation and tissue damage [27-29]. Although it is considered a non-specific biomarker, its level increases as a result of tissue damage caused by acute inflammatory events. Monitoring is, therefore, considered very useful for screening and for disease management [30]. Baseline hsCRP values in healthy subjects are below 10

Table 4 - Correlations between hsCRP and fibrinogen with clinical indicators

\begin{tabular}{|c|c|c|c|c|c|c|c|c|}
\hline Markers & Groups & $\begin{array}{c}\text { Spearman } \\
\text { Correlation } \\
\end{array}$ & $\begin{array}{c}\text { Seniority in the } \\
\text { current job }\end{array}$ & Age & BMI & SBP & DBP & HR \\
\hline \multirow{6}{*}{ hsCRP } & \multirow{2}{*}{$\begin{array}{l}\text { Workers } \\
\left(1^{\text {st }} \text { group }\right)\end{array}$} & Correlation Coeff & 0.026 & -0.191 & 0.332 & 0.306 & 0.426 & 0.025 \\
\hline & & $\mathrm{P}$ value & 0.915 & 0.420 & 0.152 & 0.233 & 0.088 & 0.926 \\
\hline & \multirow{2}{*}{$\begin{array}{l}\text { Office staff } \\
\left(2^{\text {nd }} \text { group }\right)\end{array}$} & Correlation Coeff & -0.030 & -0.034 & 0.082 & 0.084 & -0.155 & 0.568 \\
\hline & & P value & 0.895 & 0.865 & 0.679 & 0.676 & 0.440 & 0.043 \\
\hline & \multirow{2}{*}{$\begin{array}{c}\text { Control } \\
\left(3^{\text {rd }} \text { group }\right)\end{array}$} & Correlation Coeff & -0.004 & 0.043 & 0.059 & -0.208 & -0.178 & -0.196 \\
\hline & & $P$ value & 0.973 & 0.783 & 0.644 & 0.105 & 0.166 & 0.126 \\
\hline \multirow{6}{*}{$\begin{array}{l}\text { Fibrino- } \\
\text { gen }\end{array}$} & \multirow{2}{*}{$\begin{array}{l}\text { Workers } \\
\left(1^{\text {st }} \text { group }\right)\end{array}$} & Correlation Coeff & -0.010 & 0.026 & 0.013 & 0.340 & 0.340 & -0.194 \\
\hline & & $P$ value & 0.967 & 0.912 & 0.956 & 0.181 & 0.182 & 0.471 \\
\hline & \multirow{2}{*}{$\begin{array}{l}\text { Office staff } \\
\left(2^{\text {nd }} \text { group }\right)\end{array}$} & Correlation Coeff & -0.184 & -0.062 & 0.363 & -0.053 & -0.015 & 0.493 \\
\hline & & P value & 0.413 & 0.755 & 0.058 & 0.792 & 0.940 & 0.045 \\
\hline & \multirow{2}{*}{$\begin{array}{c}\text { Control } \\
\left(3^{\text {rd }} \text { group }\right)\end{array}$} & Correlation Coeff & 0.013 & -0.034 & -0.227 & -0.102 & 0.148 & 0.052 \\
\hline & & $P$ value & 0.925 & 0.831 & 0.087 & 0.452 & 0.273 & 0.700 \\
\hline
\end{tabular}

Body mass index - BMI, blood pressure - SBP, diastolic blood pressure - DBP, heart rate - HR 
$\mathrm{mg} / \mathrm{l}$. Serum hsCRP levels above $3 \mathrm{mg} / \mathrm{l}$ were found to be associated with an increased risk of cardiovascular events. Levels between 1 and 3 $\mathrm{mg} / \mathrm{l}$ are associated with an average risk of cardiovascular conditions, whereas levels below $1 \mathrm{mg} / 1$ are indicative of a low risk [31]. In our study, the hsCRP values were similar in the three groups (p-0.25) with median values of $1.04 \mathrm{mg} / \mathrm{l}$ for control, $1.42 \mathrm{mg}$ for office staff moderately exposed and of $1.92 \mathrm{mg} / \mathrm{l}$ for the workers undergoing the highest levels of exposure. Even if no statistical significance has been found, an increased level in hsCRP might imply an increased cardiovascular risk for the exposed subjects compared to control. Similar findings were reported in the study of Hui et al. [9] for workers exposed to nano-materials as compared to control.

As far as fibrinogen is concerned, the applied ANOVA test revealed a significant difference between work environments of the monitored groups. Bonferroni's multiple comparability test indicating that the mean of the fibrinogen in the control group was much lower compared to the exposed groups. Increase in fibrinogen synthesis was noted in the acute phase response to infections, inflammations, tumors, trauma, burns. It is useful in assessing the risk of cardiovascular thrombotic events (e.g. acute myocardial infarction, stroke) or acute inflammatory processes $[32,33]$. Previously, fibrinogen was also found to represent a good candidate for human biomonitoring following nanomaterials exposure in a review by Bergamaschi [34], but the author found also hsCRP to play a similar role. However, we cannot quantify the extent to which fibrinogen is influenced by UFP and/or the mixture of organic solvents. Since we did not find any suggestive data in the literature regarding the influence of exposure to organic solvents on the fibrinogen blood level, we have assumed the blood levels of fibrinogen would likely be influenced more by UFP than by organic solvents. In a transversal study of Liou et al. [35], the authors observed that the level of fibrinogen was significantly higher for high-risk workers than for controls.

Furthermore, experimental studies based on human experimental inhalation found that ultra-fine particles or particles emitted by diesel engines are inducing cardiovascular lesions by affecting vascular tone and endogenous fibrinolysis [24, 36, 37].

Also, cardiovascular consequences due to exposure to nanoparticles have been reported in several epidemiological studies [13, 38, 39]. In our study, the correlation of hsCRP and fibrinogen with distinct clinical indicators (SBP, DBP, HR) for each of the three groups did not identify significant correlations except for the heart rate in the moderately exposed group (rho correlation $0.568, \mathrm{p}-0.043)$.

To the best of our knowledge, our study is the first providing data on these inflammation markers in workers exposed to a heterogeneous mixture of UFP and organic solvents. Based on the results of our study, fibrinogen might be a suitable systemic marker for potential disease developed upon exposure to a complex mixture of UFP and organic solvents. Nevertheless, one should always consider other clinical indicators along with the fibrinogen level when assessing the worker's personal risk. According to our data, the heart rate could represent such a clinical indicator, but clinicians should take into consideration other causes of inflammation and tissue damage that could lead to an increased fibrinogen level. Normalizing plasma fibrinogen level to total leukocyte or neutrophil counts could also be helpful in the clinical judgment, as well as measuring the level of biomarkers of oxidative stress [40-44].

Anyway, our study suggests that exposure to a complex mixture of organic solvents and UFP triggers an inflammatory state and this could be used by the occupational physicians to assess the personal health risk of the exposed workers and 
to recommend further investigations, i.e. specific toxicological investigations.

We recognize the following potential limitation of our study. The samples selected were small to offer a good power for the study. In particular, the $1^{\text {st }}$ group was smaller since there are not many factories where the management team agrees with studies aimed at assessing markers designed to demonstrate that exposure to nanoparticles or solvents is a major risk to the workers' health. Additionally, there is another difficulty relating to the potential subject's acceptance of participating in a study where blood and urine samples are collected. Next, costs related to sample transport, processing, and maintenance are further hindering factors. However, the $3^{\text {rd }}$ group includes sufficient subjects compared to the groups of exposed subjects, in order to increase the statistical power.

\section{Conclusion}

Based on the results of our cross-sectional study, exposure to a mixture of UFP and organic solvents triggers an inflammatory response. Our study demonstrates that fibrinogen is a useful inflammatory biomarker for exposure to a mixture of UFP and organic solvents. On the other hand, hsCRP is not a useful inflammatory biomarker in occupational exposure to UFP and organic solvents. Further studies are needed to demonstrate the extent to which fibrinogen is more or less influenced by organic solvents or UFP alone.

\section{Acknowledgments}

Internal research grant, project no. 235/ 06.01.2016, beneficiary: University of Medicine and Pharmacy of Tîrgu Mureş/financed by the Mediconsult Association, Tîrgu Mureş.

Internal research grant, $\mathrm{C} 3$ research project no. 3M160685, financed by KU Leuven, Belgium.

\section{Conflict of interests}

The authors state that there are no conflicts of interest.

\section{List of abbreviations}

BMI-body index mass

DBP - diastolic blood pressure

FRP - fiberglass reinforced polyester

HR - heart rate

hsHS-CRP - highly-sensitive C-reactive protein

SBP - systolic blood pressure

SD - standard deviation

SPSS - Statistical Package for Social Sciences

UFP- ultrafine particles

\section{References}

1. Bekker C, Brouwer DH, Tielemans E, Pronk A. Industrial production and professional application of manufactured nanomaterials-enabled end products in Dutch industries: potential for exposure. Ann Occup Hyg. 2013;57(3):314-27.

2. Bahadar H. Mostafalou S, Abdollahi M. Current understandings and perspectives on non-Cancer health effects of benzene: A global concern. Toxicol Appl Pharmacol. 2014;276(2):83-94. DOI: 10.1016/j.taap.2014.02.012

3. Baker EL. A Review of Recent Research on Health Effects of Human Occupational Exposure to Organic Solvents. J Occup Environ Med. 1994;36(10):1079-92. DOI: 10.1097/00043764-199410000-00010

4. Mohammadi S, Mehrparvar A, Labbafinejad Y, Attarchi MS. The effect of exposure to a mixture of organic solvents on liver enzymes in an auto manufacturing plant. J Public Health. 2010;18(6):553-557. DOI: 10.1007/ s10389-010-0340-z

5. Mohammadi S, Labbafinejad Y, Attarchi M. Combined Effects of Ototoxic Solvents and Noise on Hearing in Automobile Plant Workers in Iran. Arh Hig Rada Toksikol. 2010;61(3):267-274. DOI: 10.2478/10004-125461-2010-2013

6. Lobo V, Patil A, Phatak A, Chandra N. Free radicals, antioxidants and functional foods: Impact on human health. Pharmacogn Rev. 2010;4(8):118-126. DOI: 10.4103/0973-7847.70902

7. Hesterberg TW, Long CM, Lapin CA, Hamade AK, 
Valberg PA. Diesel exhaust particulate (DEP) and nanoparticle exposures: what do DEP human clinical studies tell us about potential human health hazards of nanoparticles? Inhal Toxicol. 2010;22:679-94. DOI: $10.3109 / 08958371003758823$

8. Hubbs AF, Mercer RR, Benkovic SA, Harkema J, Sriram K, Schwegler-Berry D, et al. Nanotoxicology - a pathologist's perspective. Toxicol Pathol. 2011;39:30124. DOI: $10.1177 / 0192623310390705$

9. Hui-Yi Liao, Yu-Teh Chung, Ching-Huang Lai, Shu-Li Wang, Hung-Che Chiang et al. Six-month follow-up study of health markers of nanomaterials among. Nanotoxicology. 2013;8:100-10. DOI: 10.3109/17435390.2013.858793

10. Liou S-H, Tsai CSJ, Pelclova D, Schubauer-Berigan MK, Schulte PA. Assessing the first wave of epidemiological studies of nanomaterial workers. J Nanopart Res Journal. 2015;17(10):413. DOI: 10.1007/s11051015-3219-7

11. Vogel CFA, Sciullo E, Wong P, Kuzmicky P, Kado N, Matsumura F. Induction of proinflammatory cytokines and C-reactive protein in human macrophage cell line U937 exposed to air pollution particulates. Environ Health Perspect. 2005;113:1536-41. DOI: 10.1289/ ehp.8094

12. Li Y, Rittenhouse-Olson K, L.Scheider W, Mu L. Effect of particulate matter air pollution on $\mathrm{C}$-reactive protein: a review of epidemiologic studies, Rev Environ Health. 2012;27(2-3):133-49. DOI: 10.1515/reveh-2012-0012

13. Delfino RJ, Staimer N, Tjoa T, Polidori A, Arhami M, Gillen DL, et al. Circulating biomarkers of inflammation, antioxidant activity, and platelet activation are associated with primary combustion aerosols in subjects with coronary artery disease. Environ. Health Perspect. 2008;116:898-906. DOI: 10.1289/ehp.11189

14. OhlsonCG, BergP, BryngelssonIL, ElihnK, NgoY, Westberg $\mathrm{H}$, et al. Inflammatory markers and exposure to occupational air pollutants. Inhal. Toxicol. 2010;22:10831090. DOI: $10.3109 / 08958378.2010 .520356$

15. Niwa Y, Hiura Y, Sawamura H, Iwai N, Inhalation exposure to carbon black induces inflammatory response in rats. Circ. J. 2008;72:144-9. DOI: 10.1253/circj.72.144

16. Peters A, Greven S, Heid I. M, Baldari F, Breitner S, Bellander T. et al. Fibrinogen genes modify the fibrinogen response to ambient particulate matter. Am J Respir Crit Care Med. 2009;179:484-91. DOI: 10.1164/ recm.200805-751OC
17. Marra J, Voetz M, Kiesling HJ. Monitor for detecting and assessing exposure to airborne nanoparticles. $\mathrm{J}$ Nanopart Res. 2010;12:21-37. DOI: 10.1007/s11051009-9695-x

18. Creta M, Poels K, Thoelen L, A Method to Quantitatively Assess Dermal Exposure to Volatile Organic Compounds, Annals of Work Exposures and Health. 2017;61(8):975-85. DOI: 10.1093/annweh/wxx054

19. Clauss A. Gerinnungsphysiologische Schnellmethode zur Bestimmung des Fibrinogens. Acta Haematol. 1957;17:237-46. DOI: 10.1159/000205234

20. Donaldson K, Stone V, Seaton A, MacNee W. Ambient particle inhalation and the cardiovascular system: potential mechanisms. Environ Health Per-

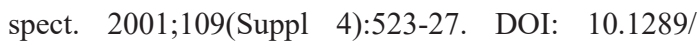
ehp.01109s4523

21. Borm PJ, Robbins D, Haubold S, Kuhlbusch T, Fissan $\mathrm{H}$, Donaldson K, et al. The potential risks of nanomaterials: a review carried out for ECETOC. Part Fibre Toxicol. 2006;3:11-45. DOI: 10.1186/1743-8977-3-11

22. Brouwer D. Exposure to manufactured nanoparticles in different workplaces. Toxicology. 2010;269:120-7. DOI: 10.1016/j.tox.2009.11.017

23. Frampton MW. Does inhalation of ultrafine particles cause pulmonary vascular effects in humans? Inhal Toxicol. 2007;19:75-9. DOI: 10.1080/08958370701495071

24. Quan C, Sun Q, Lippmann M, Chen LC. Comparative effects of inhaled diesel exhaust and ambient fine particles on inflammation, atherosclerosis, and vascular dysfunction. Inhal Toxicol. 2010;22:738-53. DOI: 10.3109/08958371003728057

25. Peters A, Breitner S, Cyrys J, Stolzel M, Pitz M, Wolke $\mathrm{G}$, et al. The influence of improved air quality on mortality risks in Erfurt, Germany. Res Rep Health Eff Inst. 2009;137:5-77.

26. Song Y, Li X, Du X. Exposure to nanoparticles is related to pleural effusion, pulmonary fibrosis and granuloma. Eur Respir J. 2009;34:559-67. DOI: 10.1183/09031936.00178308

27. Pepys MB, Hirschfield GM. C-reactive protein: A critical update. J Clin Investig. 2003;111:1805-12. DOI: 10.1172/JCI200318921

28. Simion M, Ruta Lavinia L, Kleps I, Miu M. Study of HS-CRP immobilization on nanostructured silicon. Materials Science and Engineering B, Solid-State Materials for Advanced Technology. 2010;169(1-3):67-72. DOI: $10.1016 /$ j.mseb.2009.12.050 
29. Zhang YX, Cliff WJ, Schoefl GI, Higgins G. Coronary C-reactive protein distribution: Its relation to development of atherosclerosis. Atherosclerosis. 1999;145:3759. DOI: 10.1016/S0021-9150(99)00105-7

30. McBride JD., Cooper MA. A high sensitivity assay for the inflammatory marker C-Reactive protein employing acoustic biosensing. Nanobiotechnology. 2008;6:18. DOI: $10.1186 / 1477-3155-6-5$

31. Ansar W, Ghosh S. C-reactive protein and the biology of disease. Immunol Res. 2013;56(1):131-42. DOI: 10.1007/s12026-013-8384-0

32. Pilar C, Rosana S.V, Jonathan P, González F. A quantitative binding study of fibrinogen and human serum albumin to metal oxide nanoparticles by surface plasmon resonance, Biosens Bioelectron. 2015;74:376-83. DOI: 10.1016/j.bios.2015.05.070

33. Fischbach F. Blood Studies. Hematology and Coagulation, A Manual of Laboratory and Diagnostic Test 8th ed, Philadelphia, 2009; 177-8.

34. Bergamaschi E. Human Biomonitoring of Engineered Nanoparticles: An Appraisal of Critical Issues and Potential Biomarkers. J Nanomater. 2012;2012:1-12. DOI: $10.1155 / 2012 / 564121$

35. Liou SH, Tsou TC, Wang SL, Li LA, Chiang HC, Li WF, et al. Epidemiological study of health hazards among workers handling engineered nanomaterials. J Nanopart Res Journal. 2012;14:878-82. DOI: 10.1007/ s11051-012-0878-5

36. Mills NL, Tornqvist H, Robinson SD, Gonzalez M, Darnley K, MacNeeW, et al. Diesel exhaust inhalation causes vascular dysfunction and impaired endogenous fibrinolysis. Circulation. 2005;112:3930-6. DOI: 10.1161/CIRCULATIONAHA.105.588962

37. Lucking AJ, Lundback M, Mills NL, Faratian D, Barath SL, Pourazar J, et al. Diesel exhaust inhalation increases thrombus formation in man. Eur Heart J.
2008;29:3043-51. DOI: 10.1093/eurheartj/ehn464

38. Araujo JA, Nel AE. Particulate matter and atherosclerosis: role of particle size, composition and oxidative stress. Part Fibre Toxicol. 2009;6:24-42. DOI: 10.1186/1743-8977-6-24

39. Paik SY, Zalk DM, Swuste P. Application of a pilot control banding tool for risk level assessment and control of nanoparticle exposures. Ann Occup Hyg. 2008;52:419-28.

40. Sutton RH, Hobman B. The value of plasma fibrinogen estimations in cattle: A comparison with total leucocyte and neutrophil counts. N. Z. Vet J. 1975;23(3):21-27 DOI: $10.1080 / 00480169.1975 .34186$

41. Pelclova D, Fenclova Z, Syslova K, Vlckova S, Lebedova J, Pecha O. Oxidative stress markers in exhaled breath condensate in lung fibroses are not significantly affected by systemic diseases. Ind Health. 2011;49(6):746-54. DOI: 10.2486/indhealth.MS1237

42. Pelclova D, Navratil T, Fenclova Z, Vlckova S, Kupka $\mathrm{K}$, Urban $\mathrm{P}$, et al. Increased oxidative/nitrosative stress markers measured non- invasively in patients with high 2,3,7,8-tetrachloro-dibenzo-p-dioxin plasma level. Neuro Endocrinol Lett. 2011;32Suppl 1:71-6.

43. Pelclova D, Zdimal V, Kacer P, Fenclova Z, Vlckova $\mathrm{S}$, Syslova K. et al. Oxidative stress markers are elevated in exhaled breath condensate of workers exposed to nanoparticles during iron oxide pigment production. J Breath Res. 2016;10(1):016004. DOI: 10.1088/17527155/10/1/016004

44. Fogarasi E, Croitoru MD, Fülöp I, Nemes-Nagy E, Tripon RG, Simon-Szabo Z, et al. Malondialdehyde levels can be measured in biological samples by using a fast HPLC method with visible detection. Rev Romana Med Lab. 2016;24(3):319-26. DOI: 10.1515/rrlm2016-0029 